\title{
Comparison of Fuels and Effluents Originating from Washing and Hydrothermal Carbonisation of Residual Biomass
}

\author{
Lynn J. Hansen ${ }^{1}\left[\right.$ D $\cdot$ Sebastian Fendt ${ }^{1} \cdot$ Hartmut Spliethoff $^{1}$
}

Received: 6 April 2021 / Accepted: 17 October 2021 / Published online: 15 November 2021

(c) The Author(s) 2021

\begin{abstract}
A series of four different biomass feedstock was washed and hydrothermally carbonized at temperatures of $50{ }^{\circ} \mathrm{C}$ and $150-270{ }^{\circ} \mathrm{C}$ for four hours, respectively. For the first time both the resulting solid and liquid products were characterised and evaluated in a comprehensive study. Concerning fuel properties, HTC had a higher impact on the fuel quality than washing. HTC yielded hydrochar with higher carbon content than the starting material leading to a significant increase in heating value, while washing only had a minor effect on elemental composition and heating value. Treatment temperature was found to have the highest impact on LHV and elemental composition. Both washing and HTC proved effective in reducing potassium and chlorine content, while earth alkaline, phosphorous and silicon removal was limited. Process water characterisation revealed that filtrates from washing and HTC are acidic, with acidity being increased by HTC. Electrical conductivity of the effluent was found to correlate with the amount of electrolytes $\mathrm{Na}, \mathrm{K}, \mathrm{Mg}$ and $\mathrm{Ca}$ in the feedstock, thereby being feedstock dependent. COD, $\mathrm{BOD}_{5}$ and TOC values determined revealed that effluent from both washing and HTC is strongly contaminated by organic matter. The organic load was significantly higher in HTC effluents. Feedstock type was found to be the main influencing factor on effluent characteristics rather than HTC temperature. Nutrients were found in low concentrations.
\end{abstract}

\section{Graphic Abstract}

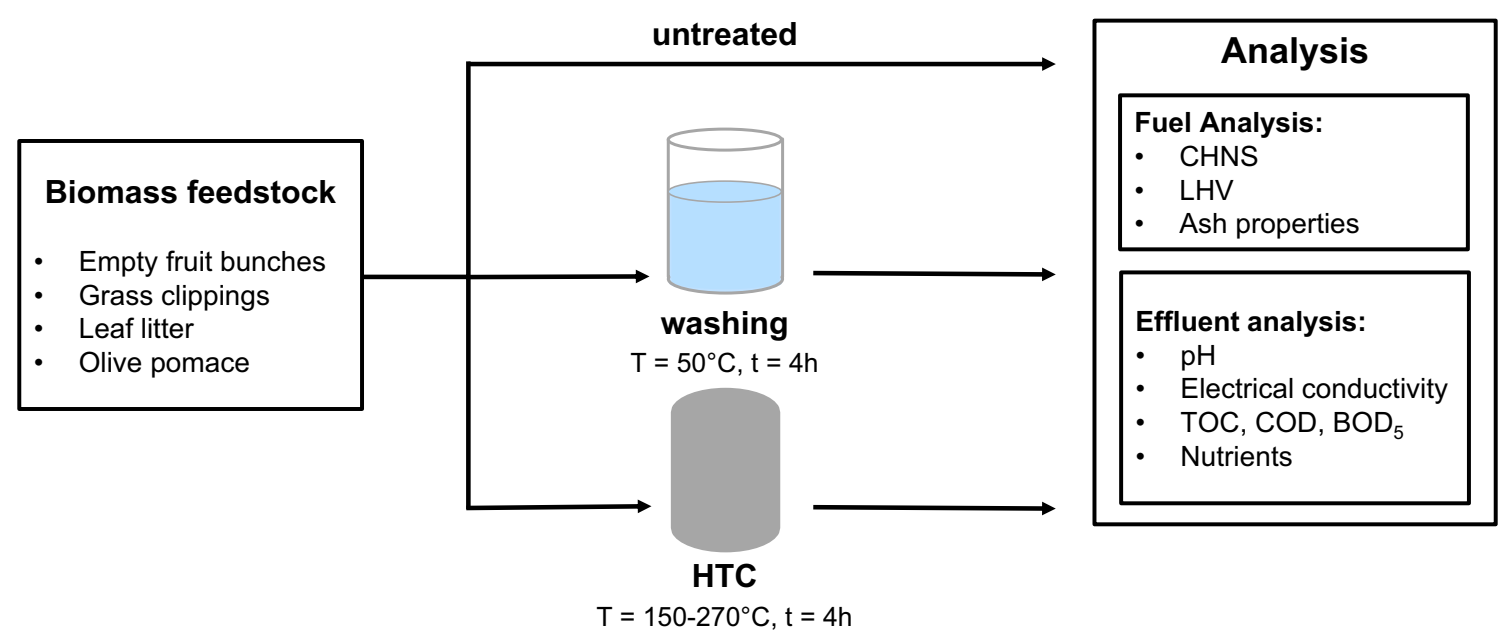

Keywords Hydrothermal carbonisation · Biomass washing $\cdot$ Effluent $\cdot$ Waste water analysis $\cdot$ Fuel quality

Lynn J. Hansen

lynn.hansen@tum.de

1 Chair of Energy Systems, Technical University of Munich, Boltzmannstraße 15, Garching, 85748 Munich, Germany 


\section{Statement of Novelty}

For the first time a comparison of biomass washing and hydrothermal carbonization (HTC) including both the characterisation of solid and liquid products is presented.

\section{Introduction}

Biomass plays a crucial role in developing a future sustainable energy system. Already today, about three-quarters of the world's renewable energy involve the use of biomass, with more than half consisting of traditional biomass use. Yet, there is a large untapped potential to further increase energetic biomass utilization. In particular, the exploitation of residual biomass waste streams seems favourable, considering no additional land-use or competition with food production is needed for its utilization. However, a large portion of available feedstock exhibit poor fuel quality such as high moisture content, inhomogeneity and low energy content which prohibit energy-efficient conversion in direct combustion or gasification. Other challenges in energetic biomass utilization arise from ash-related problems such as deposit formation, corrosion, ash-melting and particle formation [1-3]. These phenomena can be traced back to inorganic components like potassium (K) and chlorine $(\mathrm{Cl})$ that are abundant in biomass feedstock. Furthermore, about $90 \%$ of the alkali metals and chlorine in biomass are present as water-soluble or ion-exchangeable compounds and are therefore susceptible to release during combustion [1, 4-7].

A possibility to overcome these shortcomings in fuel properties is a pre-treatment of feedstock prior to its thermal conversion. Washing and a thermo-chemical treatment by hydrothermal carbonisation (HTC) have proven to be effective in reducing the amount of alkali metals and $\mathrm{Cl}$ in the upgraded biofuels. Therefore they can be applied to control ash-related issues [8-17]. Both washing and HTC alter the inorganic fuel composition by the dissolution of soluble inorganics in the process water. In addition, several factors further promote the mobilisation of inorganic matter during HTC: In this process biomass is treated in hot compressed water at a temperature range of $150-300{ }^{\circ} \mathrm{C}$. The process mimics the natural coalification process in a much faster time-scale and yields a sanitized solid product known as hydrochar or biocoal. A variety of different reactions occur during HTC, breaking down structural biomass components like hemi-cellulose and cellulose that contain a large proportion of the inorganic biomass constituents [18]. Consequently, biomass degradation might lead to a facilitation of inorganic species embedded in these structural components. Additionally, water under hydrothermal conditions has a lower density, viscosity and decreased polarity compared to water at ambient pressure and temperature [19]. These properties also potentially enhance removal of inorganics. Compared to biomass washing, HTC also helps to overcome problems associated with high moisture and low energy content of untreated feedstock. Hydrochar has increased heating value, higher hydrophobicity, and enhanced dewatering and storage properties.

A number of studies assessing the impact of washing on fuel quality exist: Turn et al. [10] have shown that up to $90 \%$ of $\mathrm{K}$ and $98 \%$ of $\mathrm{Cl}$ can be removed from banana grass by a multi-step washing procedure at ambient temperature. The impact of washing temperature from 30 to $90{ }^{\circ} \mathrm{C}$ and liquid-to-solid ratio (L/S ratio) on the removal efficiency of ash-forming matter was investigated by Deng et al. [15]. They found that higher washing temperatures lead to higher removal of ash forming constituents, while inorganic mobilisation was fluctuating at lower temperatures. Recently, an in depth study on the effect of particle size, washing temperature and duration as well as L/S ratio on fuel properties of wheat straw was published by Singhal et al. $[13,17]$. They concluded that washing temperature has a high impact on fuel quality, improving higher heating value (HHV) and lowering fouling and slagging propensity, while $\mathrm{L} / \mathrm{S}$ ratio and particle size are decisive parameters for the feasibility and efficiency of an industrial application of a washing pre-treatment step.

Studies also investigated the impact of HTC in inorganic biomass composition: Work by Smith et al. [11] and Reza et al. [12] has shown that HTC can reduce K and $\mathrm{Cl}$ contents by $80 \%-90 \%$ and $79 \%-100 \%$ respectively for a wide range of feedstock like willow, miscanthus, oak, greenhouse waste, food waste, secondary sewage sludge, digestate, macro-algae, microalgae and municipal waste. Smith et al. [20] also investigated the impact of $\mathrm{pH}$ during HTC on the combustion properties of swine manure. They found that $\mathrm{pH}$ had the highest impact on the mobilisation of phosphorous and alkali earth metals that were removed with higher efficiencies at lower $\mathrm{pH}$ levels.

To date, no comprehensive comparison between biomass upgrading by washing and HTC exists in the literature. Studies published on washing and HTC of biomass solely concentrate on the properties of the solid fuels while putting aside the characteristics of the effluents produced by both pre-treatment technologies. However, the characterisation of effluent from HTC and washing is critical for the economic and ecologic viability of the technologies. For example, in HTC per dry ton of hydrochar produced approximately $2 \mathrm{~m}^{3}$ of waste water is generated that needs to be treated at a cost [21-23]. 
Some studies characterise process water from HTC: Stemann et al. [24] and Wang et al. [25] investigated the effect of process water circulation on the properties of liquid and solid product from HTC of poplar wood and brown algae respectively. They showed that recirculation of process water increases mass yield and identified the main organic constituents in process water from hydrothermal treatment. Broch et al. [26] studied solid and liquid products from HTC of algae with a focus on high value liquid products in the process water. They showed that HTC converts approximately $1 \mathrm{wt} .-\%$ of the starting material to high value chemicals like malonic or lactic acid. Several other investigations exist that identify chemical constituents of process water [27-30]. Other studies focus on assessing the HTC carbon balance and evaluating the anaerobic digestibility of the process liquor by determining the biomethane production potential (BMP) [31-36]. To the author's knowledge up to now, no comprehensive study exists on the characterisation of effluent from biomass washing. Abelha et al. [37] have determined COD and BMP for effluents from biomass washing in their techno-economic assessment of biomass washing and torrefaction, but do not explicitly report the obtained values.

Thus, the objective of the presented study is to compare the performance of washing and HTC in fuel upgrading and characterising the resulting effluents from the two pre-treatment technologies. For the first time, both, fuel properties and effluent characterisation is included. The study covers a variety of feedstock and process conditions: four different residual biomass substrates have been washed at $50 \mathrm{C}$ and hydrothermally treated at temperatures ranging from 150 to $270{ }^{\circ} \mathrm{C}$ for a duration of $4 \mathrm{~h}$. The L/S ratio is kept constant at 1:10. Fuel properties of raw, washed and HTC-treated feedstock are investigated and improvements concerning heating value and inorganic composition evaluated. Further, all fundamental waste water analysis parameters are covered. That includes organic pollutants by total organic carbon (TOC), chemical oxygen demand (COD), biological oxygen demand (BOD), nutrient concentration, as well as basic characterization of electrical conductivity (EC) and $\mathrm{pH}$ value. An assessment of the use of effluents in anaerobic digestion (AD) is provided on basis of $\mathrm{COD}$ and $\mathrm{C} / \mathrm{N}$ ratio. The differences between washing and hydrothermal treatment are discussed.

\section{Materials and Methods}

\section{Feedstock}

Four different residual biomass feedstock were investigated in this study. Empty fruit bunches were imported from Malaysia, grass clippings and leaf litter were picked up from a local composting plant and olive pomace was retrieved from an oil mill in France. All feedstock were dried at ambient conditions and milled to a particle size below $1 \mathrm{~mm}$ prior to treatment.

\section{HTC and Washing Experiments}

Washing and HTC experiments were conducted in a stirred Parr Mini Reactor with a volume of $600 \mathrm{~mL}$ that is heated by three $700 \mathrm{~W}$ electrical heating jackets. In each experiment $30 \mathrm{~g}$ of dry feedstock and $300 \mathrm{~mL}$ deionized water were poured into the reactor. The system was then pressurized with argon and brought to reaction temperature at a heating rate of $7 \mathrm{~K} \mathrm{~min}^{-1}$. Throughout the experiment the pressure was kept constant with a backpressure regulator and temperature was controlled with an accuracy of $\pm 1{ }^{\circ} \mathrm{C}$ with a PID controller. After 4 residence time the reactor is air-cooled to room temperature and the slurry filtered to separate effluent and solid product. In this study biomass was carbonized at temperatures and pressure of $150{ }^{\circ} \mathrm{C} / 20 \mathrm{bar}, 180{ }^{\circ} \mathrm{C} / 20 \mathrm{bar}$, $210{ }^{\circ} \mathrm{C} / 40$ bar, $240{ }^{\circ} \mathrm{C} / 40$ bar and $270{ }^{\circ} \mathrm{C} / 80$ bar. Water leaching of biomass was conducted in the same experimental set-up. $30 \mathrm{~g}$ of dry feedstock were mixed with $300 \mathrm{~mL}$ of deionized water. Water washing took place at $50{ }^{\circ} \mathrm{C}$, ambient pressure and atmosphere in a stirred vessel.

\section{Fuel Characterisation}

The isolated solid product from washing and HTC was dried at ambient conditions prior to analysis. Proximate and ultimate analysis were conducted according to industrial standards: EN ISO 18134-3:2015 for the moisture content, EN14775:2009 for determination of ash content and ISO 562:1998 for the volatile content using a moisture analyzer Denver IR60 and a muffle furnace. The amount of fixed carbon was calculated by closing the mass balance. Ultimate analysis was done according to industrial standard method ISO/CD 12902:2006-11 using an elemental analyzer Vario Marco Cube from elementar. The chlorine content was determined in a similar device vario MACRO cube, also from elementar. The heating value was determined according to ISO 1928:1995 with bomb calorimeter C 200 from IKA. Ash compositions were determined by X-ray fluorescence (XRF) after complete combustion of the samples at $550{ }^{\circ} \mathrm{C}$ according to EN14775:2009. For ash composition analysis, the instrument Shimadzu EDX-800 HS was used. For the determination of ash composition Norm EN14775:2009 for fuel ashes by means of compressed tablets was used. The pellet contained $100 \mathrm{mg}$ of the test ash and $20 \mathrm{mg}$ of a wax binder. All measurements were repeated at least two times depending also on the required number of repetitions by the industrial norms. The industrial norms have strict rules for the threshold discrepancy between measurements above with the measurements needs to be repeated more often. The experimental repeatability was checked by repeating 
the treatment of EFB at $180{ }^{\circ} \mathrm{C}$ three times. The discrepancy between different experiments was found to be within an acceptable range (see supplementary material).

\section{Effluent Characterization}

Electrical conductivity and $\mathrm{pH}$ value were determined at room temperature following filtration with conductivity meter GMH 3431 and pH meter GMH 3511 from Greisinger. Subsequently, effluent samples were frozen and stored. Additional water characterisation was carried out by an external lab: TOC was determined according to EN 1484, DEV H3, BOD $_{5}$ according to DIN EN 1899-1. COD, total phosphorous $\left(\mathrm{P}_{\text {tot }}\right)$, total nitrogen $(\mathrm{TN})$, nitrate $\left(\mathrm{NO}_{3}-\mathrm{N}\right)$, nitrite $\left(\mathrm{NO}_{2}-\mathrm{N}\right)$ and ammonium $\left(\mathrm{NH}_{4}-\mathrm{N}\right)$ concentrations were characterised using Lange cuvette tests.

\section{Results and Discussion}

\section{Fuel Characterisation}

\section{Mass- and Energy Yield, Heating Values}

Table 1 shows the obtained mass- and energy yields as well as the results of proximate and ultimate analysis on dry basis after washing and hydrothermal treatment, respectively. Depending on the feedstock, around $72 \%-91 \%$ of the initial mass is obtained after water washing and filtration. After HTC, mass yield is lower and steadily decreases with increasing treatment temperature. At the lowest HTC temperature of $150{ }^{\circ} \mathrm{C}$ obtained mass yields are in the range of $58 \%-80 \%$, while at the highest treatment temperature of $270{ }^{\circ} \mathrm{C}$ only $33 \%-50 \%$ of the initial mass is retained in the hydrochar. The mass loss after washing is a consequence of removal of extractives, i.e. water soluble non-structural biomass materials that are dissolved. Under hydrothermal condition more severe structural changes are induced: at around $150{ }^{\circ} \mathrm{C}$ decarboxylation of unstable carbonyl-groups takes place. The degradation of hemi-cellulose and cellulose starts at $180{ }^{\circ} \mathrm{C}$ and $220^{\circ} \mathrm{C}$ respectively, leading to the formation of smaller water soluble organics. These fragments are removed with the process water, thereby decreasing mass yield at higher HTC temperatures. These transformations also lead to changes in elemental composition in the washed and HTC treated fuels respectively. Figure 1 shows a van Krevelen plot of atomic $\mathrm{H} / \mathrm{C}$ and atomic $\mathrm{O} / \mathrm{C}$ ratios that allows to identify the governing coalification mechanisms. Typical regions for biomass, peat, lignite and coal are indicated. The untreated biomass samples can be found in the upper right corner of the diagram in the typical biomass region. Washing leads to a slight decrease in atomic $\mathrm{H} / \mathrm{C}$ of the washed material. HTC leads to more extensive changes in atomic $\mathrm{H} / \mathrm{C}$ and $\mathrm{O} / \mathrm{C}$ ratios and with increasing treatment temperature hydrochars become increasingly similar to a low-rank coal in terms of elemental composition. As Fig. 1 indicates, the coalification mechanism during HTC seems to be governed by dehydration and decarboxylation reactions, as previously described in detail [38, 39]. These transformations in elemental composition are accompanied by changes in lower heating value (LHV). HTC significantly increases LHV due to structural changes that ultimately lead to a higher carbon content in the hydrochar. LHV increases with increasing treatment temperature, i.e. hydrochar from olive pomace treated at $150{ }^{\circ} \mathrm{C}$ exhibits a LHV of $22.12 \mathrm{MJ} \mathrm{kg}^{-1}$, which increases to $30.52 \mathrm{MJ} \mathrm{kg}^{-1}$ for olive pomace treated at $270{ }^{\circ} \mathrm{C}$. Similar increases in heating value have been reported in many other studies $[11,12$, $21,40,41]$. After washing, for EFB, grass clippings and olive pomace the obtained LHVs are slightly increased from 19.12 to $19.40 \mathrm{MJ} \mathrm{kg}^{-1}$, from 20.65 to $20.73 \mathrm{MJ} \mathrm{kg}^{-1}$ and from 17.08 to $17.92 \mathrm{MJ} \mathrm{kg}^{-1}$ respectively. This is in line with the findings from Singhal et al. [13], who also reported increased energy content after biomass washing. A reason for this could be removal of energy deficient extractives and, to a certain extent, removal of inorganic components. The LHV of fallen leaves was slightly reduced after washing.

The energy efficiency of both processes can be assessed by considering the energy yield, that is calculated by multiplication of the obtained mass yield times the ratio of LHV of the treated and untreated biomass. After washing energy yield is generally higher than energy yield after HTC. For example, washing of olive pomace yields $85 \%$ of the biomass energy input, while after HTC at $180{ }^{\circ} \mathrm{C}$ $73 \%$ of the feedstock energy are recovered in the solid product. At higher HTC temperatures, the efficiency losses due to the dissolution of organic material to the process water can, to some extent, be compensated by a higher energy densification during. For example, while mass loss strongly decreases by 15 percentage points from 63 to $48 \%$ after increasing HTC temperature from $180{ }^{\circ} \mathrm{C}$ to $270{ }^{\circ} \mathrm{C}$, energy yield only decreases by 7 points from $79 \%$ to $72 \%$.

In conclusion one can say that HTC fundamentally changes biomass structure. This leads to more favourable fuel properties in terms of energy density, LHV and carbon content. Moreover, the structural changes also lead to altered fuel properties that are not investigated within the scope of this work but elsewhere [42-44]: HTC treated material has increased hydrophobicity, can be stored outdoors, is resistant to microbial deterioration and requires less milling energy. On the other hand, the changes of the organic structure induced by washing are much smaller. However, in most cases washing slightly increases LHV and leads to a reduced atomic $\mathrm{H} / \mathrm{C}$ ratio due to the removal of extractives and ash forming matter. 


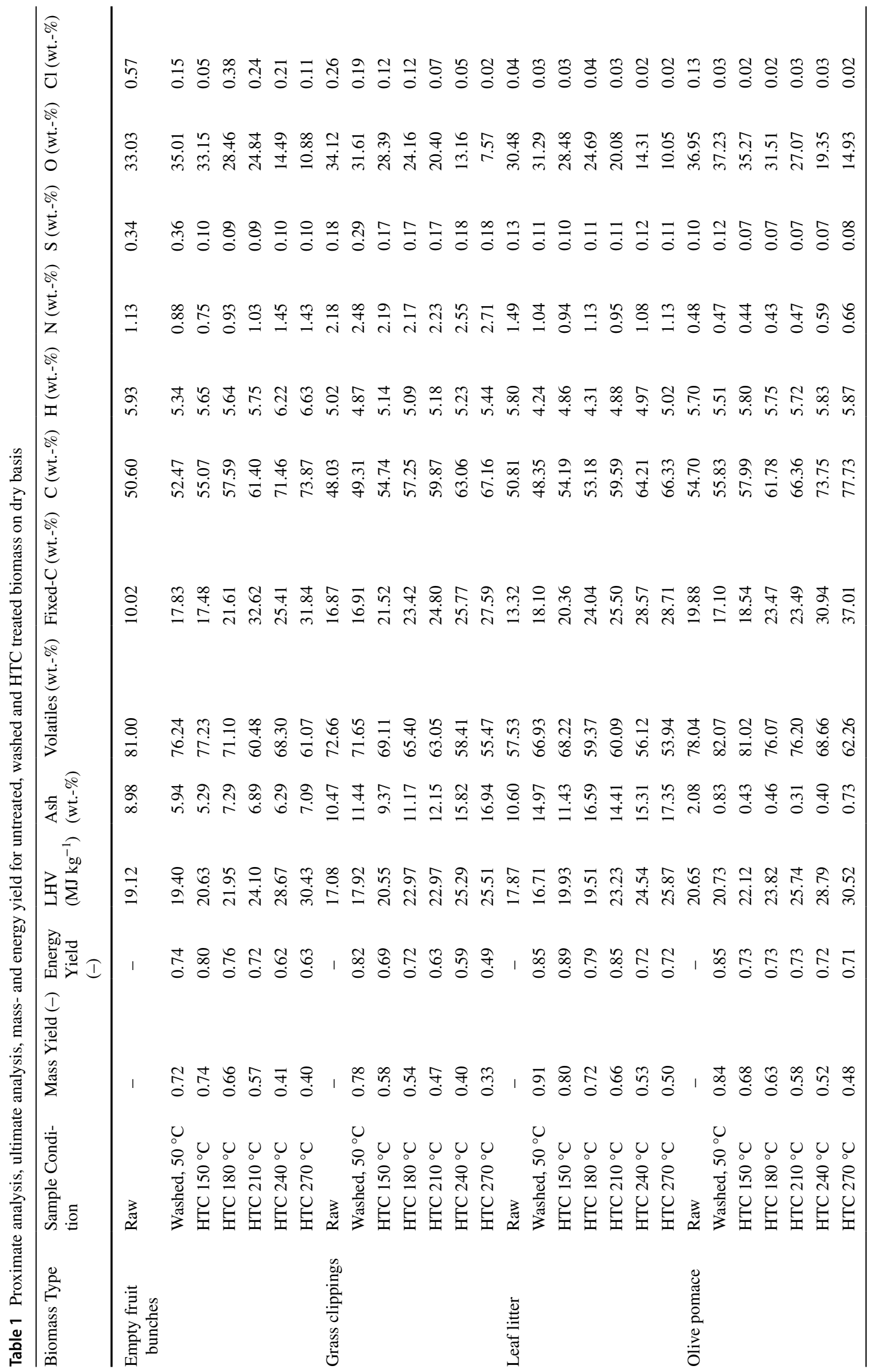




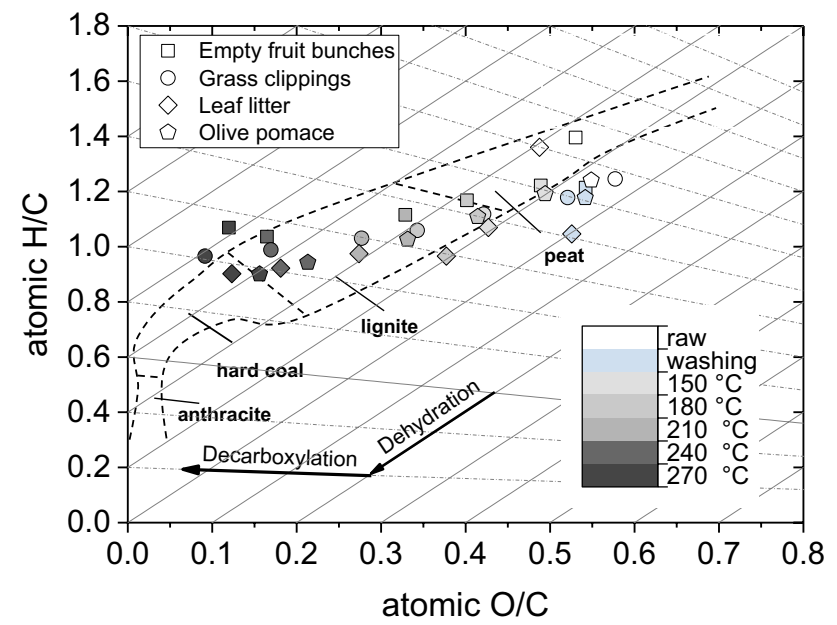

Fig. 1 Van Krevelen diagram showing the composition of empty fruit bunches, grass clippings, leaf litter and olive pomace in raw condition and after washing or HTC treatment at different temperatures for $4 \mathrm{~h}$

\section{Fate of Inorganic Elements}

The ash content of untreated, washed and HTC treated biomass samples are shown in Fig. 2a. It can be seen that the development of ash concentration in the fuel is feedstock dependent: For EFB and olive pomace washing and HTC leads to a lower ash content after treatment. Washing EFB decreases ash content from 8.9 wt.- $\%$ to 5.9 wt.-\%. HTC at $150{ }^{\circ} \mathrm{C}$ further decreases ash content to $5.3 \mathrm{wt} . \%$. Further increasing treatment temperature leads to a slight increase of ash content in HTC treated EFB to 7.1 wt.- $\%$ at $270{ }^{\circ} \mathrm{C}$. Similar behaviour is noted for olive pomace. In contrast, when treating grass clippings and leaf litter by washing or HTC a higher ash content after the pre-treatment is observed. For these feedstock, increasing the treatment temperature above $150{ }^{\circ} \mathrm{C}$ increases the ash content of the treated material steeply. For example, washing of grass clippings increases ash content from 10.47 wt.-\% to 11.44 wt.-\%, after a treatment at $150{ }^{\circ} \mathrm{C}$ the ash content is slightly decreased to 9.37 wt.- $\%$, before increasing to $15.82 \mathrm{wt} .-\%$ in biomass treated at $270{ }^{\circ} \mathrm{C}$. These observations can be explained with two effects: On the one hand, the dissolution of soluble inorganics like e.g. alkali metals leads to a reduction of inorganics in the fuel and, thus, to a lower ash content after treatment. However, at the same time organic material is dissolved in the process water during treatment as well, leading to an increased relative inorganic concentration in the material. Consequently, ash content decreases if the amount of inorganic material removed exceeds the amount of organic material removed during the treatment. It seems ash content after washing and HTC is decreased for feedstock that exhibit a high concentration of soluble species like potassium in their ash. For example, potassium content in ash from EFB and olive pomace is $41.77 \mathrm{wt} .-\%$ and $59.52 \mathrm{wt} .-\%$ respectively. In contrast, silicon, phosphorous and calcium are main ash forming elements in substrates that show higher ash content after treatment. These are elements that are known to form less water soluble compounds in biomass and therefore are extracted to a lesser extent by washing and HTC. This observation is illustrated by Fig. $2 b$ that shows the removal efficiency of washing and HTC for the main ash forming elements in EFB. The removal efficiency was calculated by subtracting the ratio of the inorganic element content of the hydrochar with the raw feedstock multiplied
Fig. 2 Ash content of raw, washed and HTC treated feedstock (a). Removal efficiency of washing and HTC in removing inorganic elements from EFB (b) (a)
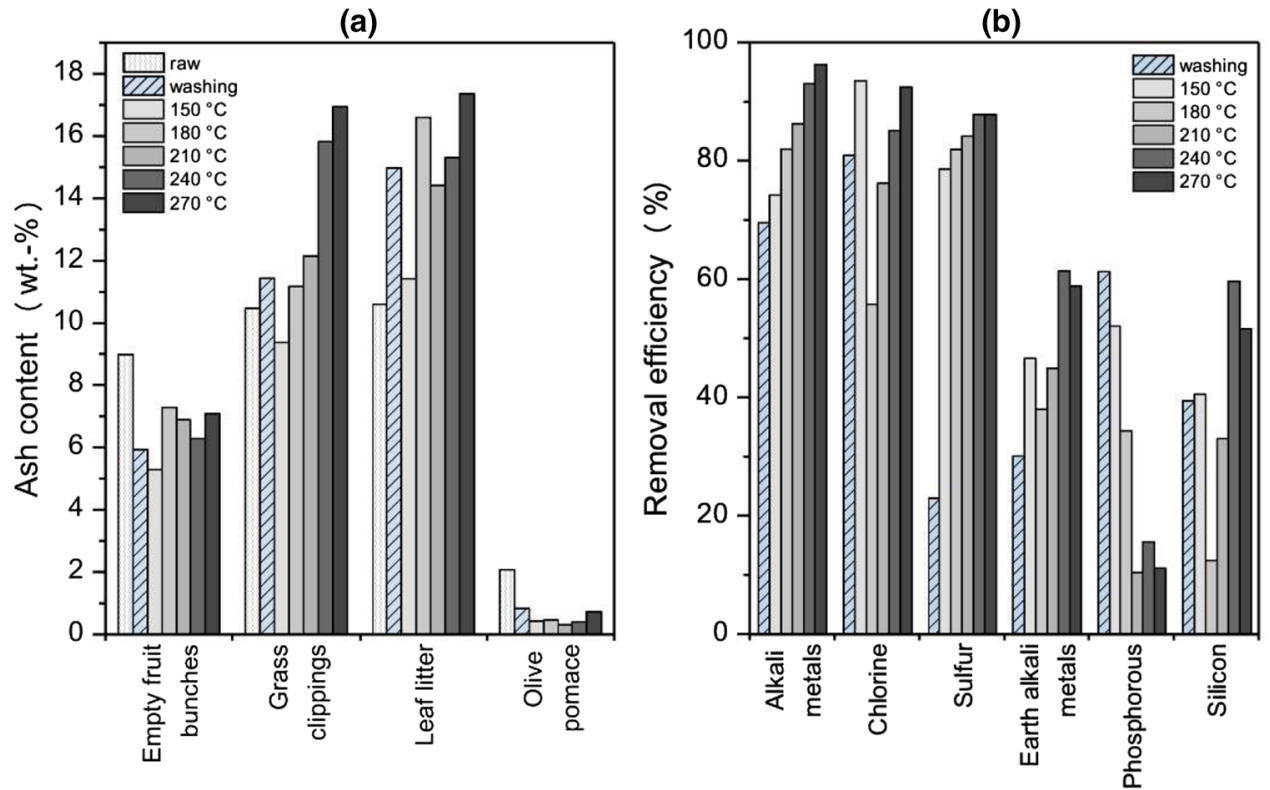
by the mass yield from 100 percent, as also applied by Smith et al. [11]. Ash analysis data for all other investigated feedstock is provided in the supplementary material. The following observations are discussed representatively for EFB. $70 \%$ of alkali metals are removed by washing of EFB. HTC increases this proportion with increasing treatment temperature to $96 \%$ for feedstock treated at $270{ }^{\circ} \mathrm{C}$. The efficiency of washing and HTC in removing chlorine is also high: Washing removed $81 \%$ and HTC between $56-94 \%$ of chlorine from the feedstock. However, in this case, no clear trend with treatment temperature is observed. Consequently, the risk of chlorine induced corrosion is reduced after washing and HTC. Sulphur removal is $23 \%$ after washing of EFB. HTC sulphur extraction is much stronger and removes $78 \%$ at $150{ }^{\circ} \mathrm{C}$ and up to $88 \%$ at $270{ }^{\circ} \mathrm{C}$. For earth alkali metals, phosphorous and silicon removal efficiencies are lower. HTC is more efficient than washing in removing earth alkali metals from EFB, increasing the proportion from $30 \%$ at washing conditions to $60 \%$ at $270{ }^{\circ} \mathrm{C}$ HTC conditions. Phosphorous removal seems to be higher after washing $(61 \%)$ than after HTC, where the removed fraction of phosphorous decreases from $52 \%$ at $150{ }^{\circ} \mathrm{C}$ to $11 \%$ at $270{ }^{\circ} \mathrm{C}$. This suggest that after a dissolution at lower temperatures $\mathrm{P}$ is reincorporated into the hydrochar during the treatment. For Si also lower overall removal efficiencies are observed. Washing removes $39 \%$ of the initially present $\mathrm{Si}$. For HTC treated EFB, the Si removal efficiency shows no clear trend with treatment temperature and remains between $15 \%$ and $60 \%$. Consequently, this study supports previous findings, that the inorganic removal efficiency of inorganics is highest for alkali metals and $\mathrm{C}$, while removal of earth alkaline metals, $\mathrm{Si}$ and $\mathrm{P}$ is limited $[9,11,12]$.

The effect of these changes in ash composition on fuel quality and ash related challenges can be assessed using fuel indices. Figure 3 shows the slagging index and base-to-acid ratio, an indicator for fouling tendency of untreated, washed and HTC treated samples. According to these indices, slagging and fouling has to be expected for all considered fuels. The highest slagging risk is expected for fuels from leaf litter, EFB poses the lowest slagging risk. The impact of washing and HTC on the slagging index is limited. Washing grass clippings and leaf litter increases the slagging index slightly, however for olive pomace and EFB a lower value, indicating higher slagging risk, is obtained. Similarly for HTC treated fuels for some substrates and process conditions, a slight amelioration of the slagging index is reached, while for others a higher risk of slagging after HTC has to be expected. In light of the findings on element removal, it is expected that the slagging index is not affected much by washing and HTC. It is calculated on the basis of the concentration of $\mathrm{Si}, \mathrm{Ca}, \mathrm{Fe}$ and $\mathrm{Mg}$ in the fuel ash. As discussed above, no strong removal on either of these inorganic species is observed in washing and HTC, therefore the impact of these pre-treatments on the slagging tendency is limited. On the other hand, washing and HTC have a stronger impact on fouling tendency, predicted by the base-to-acid ratio. For grass clippings washing reduces the $\mathrm{B} / \mathrm{A}$ ratio from 2.4 to 1.9. HTC further decreases the $B / A$ ratio with increasing treatment temperature, for example at $270{ }^{\circ} \mathrm{C}$ it is 1.3. Similar observations are made for the other substrates. However, also after pre-treatment a value of $\mathrm{B} / \mathrm{A}$ below 0.45 is not reached, which is the threshold value for a low fouling risk. Thus, washing and HTC lessen but do not fully prevent fouling risk.

To sum up, both washing and HTC significantly decrease $\mathrm{K}$ and $\mathrm{Cl}$ concentration in biomass, ameliorating fuel properties with respect to ash-related challenges in biomass combustion. This leads to a lower risk for corrosion and fouling
Fig. 3 Slagging Index $\mathbf{a}$ and base to acid ratio $\mathbf{b}$ of raw, washed and HTC treated fuels (a)

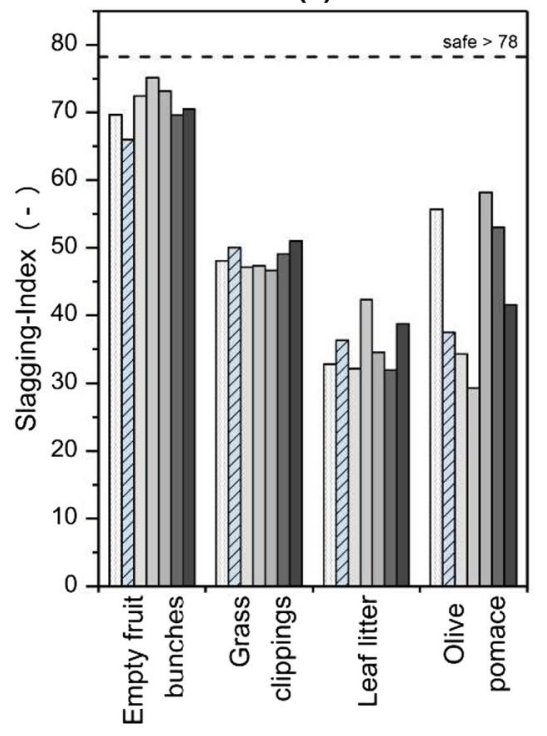

(b)

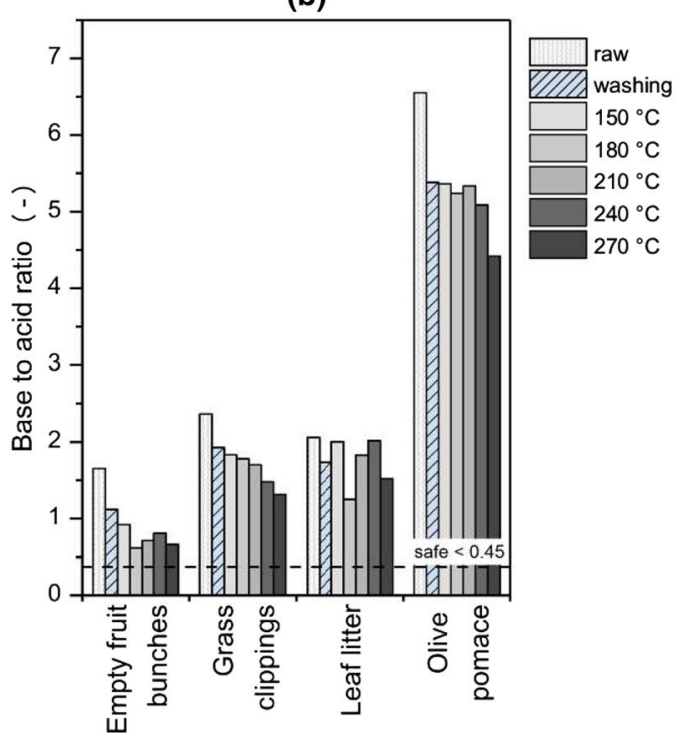


for washed or HTC treated fuels, while slagging tendency as indicated by the slagging index is not strongly altered after pre-treatment.

\section{Effluent Characterisation}

\section{pH Value}

The full set of water analysis data is presented in Table 2 . The effluent $\mathrm{pH}$ value is in the acidic range for all samples. For effluents from washed materials the $\mathrm{pH}$ value lies between 4.7 and 6.7. Effluent obtained from the HTC experiments was generally more acidic with a range from 3.6 to 5.2. After HTC the obtained $\mathrm{pH}$ values are fairly similar and only minor differences between different feedstock can be observed. After washing differences between feedstock are more pronounced. $\mathrm{pH}$ levels after HTC are fairly stable when increasing treatment temperature from $150{ }^{\circ} \mathrm{C}$ to $270{ }^{\circ} \mathrm{C}$. For EFB and leaf litter a slight decrease with increasing treatment temperature can be observed. For grass clippings and olive pomace on the other hand, $\mathrm{pH}$ slightly increases for increasing treatment temperature. Overall, a further increase in HTC temperature does not lead to further significant changes in $\mathrm{pH}$ value. The decrease of $\mathrm{pH}$ after HTC, as also reported by other researchers, can be explained with biomass degradation during HTC that leads of the formation of several organic acids such as acetic, formic, lactic and propionic acid [24, 26, 35, 45].

\section{Electrical Conductivity}

The electrical conductivity (EC) of the investigated effluent samples shows a high variability in the range of $1.9-6.3 \mathrm{mS} \mathrm{cm}^{-1}$. The highest conductivity is obtained for effluent from HTC of grass clippings. Compared to washing HTC yields higher EC in the effluent. Further increasing HTC treatment temperature does not seem to have a strong effect on the EC of the effluent obtained after reaction. Effluent from leaf litter and grass clippings shows a maximum in EC at about $210{ }^{\circ} \mathrm{C}$, it decreases again for higher temperatures. EC slightly decreases in effluent form olive pomace with increasing treatment temperature, while no clear trend is seen for EFB. Compared to $\mathrm{pH}$, a higher variability of $\mathrm{EC}$ with feedstock type is observed. The range in which the EC of sample effluent spreads seems to be feedstock dependent.

Table 2 Water analysis data of effluent obtained from washing and hydrothermal carbonisation at different temperatures of various feedstock

\begin{tabular}{|c|c|c|c|c|c|c|c|c|c|c|c|}
\hline Biomass type & $\begin{array}{l}\text { Treatment } \\
\text { Conditions }\end{array}$ & $\begin{array}{l}\mathrm{pH} \\
(-)\end{array}$ & $\begin{array}{l}\text { Electrical con- } \\
\text { ductivity (mS } \\
\left.\mathrm{cm}^{-1}\right)\end{array}$ & $\begin{array}{l}\text { TOC } \\
\left(\mathrm{mg} \mathrm{l}^{-1}\right)\end{array}$ & $\begin{array}{l}\mathrm{BOD}_{5} \\
\left(\mathrm{mg} \mathrm{l}^{-1}\right)\end{array}$ & $\begin{array}{l}\text { COD } \\
\left(\mathrm{mg} \mathrm{l}^{-1}\right)\end{array}$ & $\begin{array}{l}\mathrm{P}_{\text {tot }} \\
\left(\mathrm{mg} \mathrm{1^{-1 }}\right)\end{array}$ & $\begin{array}{l}\mathrm{TN} \\
\left(\mathrm{mg} \mathrm{l}^{-1}\right)\end{array}$ & $\begin{array}{l}\mathrm{NO}_{3}-\mathrm{N} \\
\left(\mathrm{mg} \mathrm{l}^{-1}\right)\end{array}$ & $\begin{array}{l}\mathrm{NO}_{2}-\mathrm{N} \\
\left(\mathrm{mg} \mathrm{l}^{-1}\right)\end{array}$ & $\begin{array}{l}\mathrm{NH}_{4}-\mathrm{N} \\
\left(\mathrm{mg} \mathrm{l}^{-1}\right)\end{array}$ \\
\hline \multirow[t]{6}{*}{ Empty fruit bunches } & Washed, $50{ }^{\circ} \mathrm{C}$ & 5.78 & 4.71 & 3880 & 6380 & 11,805 & 75.4 & 216 & 30 & 1.34 & 18.90 \\
\hline & $\mathrm{HTC} 150^{\circ} \mathrm{C}$ & 4.54 & 4.83 & 9120 & 11,780 & 22,775 & 73.0 & 394 & 79 & 0.48 & 34.40 \\
\hline & $\mathrm{HTC} 180^{\circ} \mathrm{C}$ & 4.02 & 4.84 & 9315 & 15,040 & 24,640 & 64.4 & 452 & 122 & 0.30 & 0.88 \\
\hline & HTC $210^{\circ} \mathrm{C}$ & 4.14 & 4.22 & 9870 & 15,440 & 24,940 & 19.0 & 398 & 119 & 0.30 & 1.36 \\
\hline & $\mathrm{HTC} 240^{\circ} \mathrm{C}$ & 4.12 & 4.08 & 11,400 & 16,240 & 28,905 & 11.8 & 398 & 91 & 0.30 & 1.72 \\
\hline & $\mathrm{HTC} 270^{\circ} \mathrm{C}$ & 4.12 & 5.07 & 11,370 & 19,840 & 29,170 & 10.8 & 320 & 94 & 0.96 & 4.22 \\
\hline \multirow[t]{6}{*}{ Grass clippings } & Washed, $50^{\circ} \mathrm{C}$ & 5.94 & 4.43 & 9650 & 19,440 & 25,240 & 238.0 & 484 & 117 & 1.00 & 20.40 \\
\hline & $\operatorname{HTC} 150{ }^{\circ} \mathrm{C}$ & 4.35 & 5.82 & 14,340 & 22,640 & 37,500 & 53.4 & 780 & 184 & 1.10 & 1.56 \\
\hline & $\mathrm{HTC} 180^{\circ} \mathrm{C}$ & 4.45 & 6.17 & 13,700 & 20,240 & 31,650 & 12.0 & 1022 & 136 & 0.90 & 1.26 \\
\hline & $\mathrm{HTC} 210^{\circ} \mathrm{C}$ & 4.62 & 6.20 & 14,600 & 19,440 & 34,630 & 6.3 & 1010 & 141 & 0.98 & 1.34 \\
\hline & $\mathrm{HTC} 240{ }^{\circ} \mathrm{C}$ & 4.96 & 6.27 & 12,980 & 19,840 & 32,510 & 4.6 & 1006 & 113 & 0.70 & 2.06 \\
\hline & HTC $270{ }^{\circ} \mathrm{C}$ & 5.23 & 5.76 & 12,370 & 17,440 & 31,200 & 4.2 & 786 & 103 & 0.44 & 4.76 \\
\hline \multirow[t]{6}{*}{ Leaf litter } & Washed, $50^{\circ} \mathrm{C}$ & 6.71 & 2.46 & 536 & 660 & 1602 & 18.2 & 33 & 13 & 0.36 & 2.92 \\
\hline & $\mathrm{HTC} 150^{\circ} \mathrm{C}$ & 4.91 & 2.72 & 7680 & 12,640 & 19,500 & 17.0 & 173 & 71 & 0.86 & 25.6 \\
\hline & $\mathrm{HTC} 180^{\circ} \mathrm{C}$ & 4.95 & 3.73 & 6565 & 9040 & 15,410 & 5.2 & 268 & 87 & 1.00 & 4.20 \\
\hline & $\mathrm{HTC} 210^{\circ} \mathrm{C}$ & 4.55 & 3.43 & 8055 & 12,240 & 19,900 & 1.8 & 226 & 90 & 0.94 & 2.40 \\
\hline & $\mathrm{HTC} 240^{\circ} \mathrm{C}$ & 4.44 & 3.78 & 8480 & 14,240 & 22,525 & 1.0 & 256 & 71 & 0.58 & 1.92 \\
\hline & $\mathrm{HTC} 270^{\circ} \mathrm{C}$ & 4.75 & 3.22 & 8770 & 13,840 & 22,480 & 1.0 & 268 & 66 & 0.30 & 4.02 \\
\hline \multirow[t]{5}{*}{ Olive pomace } & Washed, $50^{\circ} \mathrm{C}$ & 4.70 & 1.89 & 2390 & 2980 & 6545 & 49.8 & 25 & 46 & 0.64 & 0.54 \\
\hline & $\mathrm{HTC} 180^{\circ} \mathrm{C}$ & 3.56 & 2.57 & 10,850 & 18,240 & 25,840 & 57.6 & 152 & 163 & 0.30 & 0.56 \\
\hline & $\mathrm{HTC} 210^{\circ} \mathrm{C}$ & 3.80 & 2.53 & 8860 & 14,640 & 21,975 & 48.0 & 134 & 120 & 0.30 & 0.70 \\
\hline & $\mathrm{HTC} 240^{\circ} \mathrm{C}$ & 3.77 & 2.25 & 9920 & 16,000 & 25,565 & 30.8 & 107 & 88 & 0.30 & 1.06 \\
\hline & HTC $270^{\circ} \mathrm{C}$ & 3.65 & 2.29 & 9760 & 16,640 & 26,820 & 22.8 & 119 & 81 & 0.30 & 1.62 \\
\hline
\end{tabular}


$\mathrm{EC}$ is directly related to the concentration of ions in the water. During washing and HTC soluble inorganics are extracted from biomass and are dissolved in the effluent water. Thus, the higher level of EC after HTC indicates that HTC is more efficient in the extraction of inorganics from the biomass matrix. After washing EC is lower compared to the EC of HTC effluent. There is no clear further trend of EC with temperature. Feedstock like EFB and grass clippings, which are rich in soluble alkali and earth alkali metals while also possessing high ash content, exhibit the highest EC in the resulting HTC effluent and washing effluent. The lowest ECs were measured for effluents from olive pomace that has a low ash content of $5 \mathrm{wt} .-\%$.

\section{Organic Matter and AD Usability}

Table 2 shows the measured concentrations for total organic carbon (TOC), biological oxygen demand after 5 days $\left(\mathrm{BOD}_{5}\right)$ and chemical oxygen demand (COD) in the effluent from biomass washing and HTC treatment of biomass. TOC values after washing lie within a range of 536-9650 $\mathrm{mg} \mathrm{l}^{-1}$ Compared to this, TOC values are increased significantly after HTC and are within 6565-14,600 $\mathrm{mg}^{-1}$. An exception to this is effluent from grass clippings where TOC of effluent from washed material reaches equally high TOC values as effluent originating from HTC. For comparison, Erdogan et al. [35] reported equally high values between 15,000 and 25,000 $\mathrm{mg} \mathrm{l}^{-1}$ for effluent from HTC of orange pomace. Berge et al. [46] found concentrations of TOC in the range of 5000-35,700 $\mathrm{mg}^{-1}$ in effluent from HTC of municipal biomass waste streams. These values indicate a heavy pollution of process water with organic material originating from biomass degradation processes during
HTC. For EFB with increasing HTC temperature also an increase in TOC is observed. For the other feedstock, no clear development of TOC with temperature is noted. Again differences in TOC are governed by feedstock type with leaf litter exhibiting lower TOC values of up to approximately $15,000 \mathrm{mg} \mathrm{l}^{-1}$ in comparison to effluent from grass cuttings, olive pomace and EFB where TOC reaches values above $15,000 \mathrm{mg} \mathrm{l}^{-1}$. For $\mathrm{BOD}_{5}$ and COD similar observations can be made: COD of effluent obtained after washing is significantly lower than COD of effluent obtained after HTC of the same feedstock. COD values after washing show higher variance and reach values between 1602 and $25,240 \mathrm{mg}^{-1}$, whereas after HTC, COD values lie in a more narrow range of $15,410-37,500 \mathrm{mg} \mathrm{l}^{-1}$. COD of HTC effluents seems to be determined by feedstock type rather than treatment temperature. $\mathrm{BOD}_{5}$ values follow the same trends. After washing $\mathrm{BOD}_{5}$ values are significantly lower than after HTC. For example, effluent from washing of EFB yielded a $\mathrm{BOD}_{5}$ of $6380 \mathrm{mg} \mathrm{l}^{-1}$ and more than doubled to $15,040 \mathrm{mg} \mathrm{l}^{-1}$ in effluent from EFB HTC treated at $180{ }^{\circ} \mathrm{C}$. Compared to the COD values the $\mathrm{BOD}_{5}$ values are relatively high. Consequently, a good biodegradability of the organic substances is to be expected. The $\mathrm{BOD}_{5} / \mathrm{COD}$ ratio for effluent from washing varies from 0.41 to 0.77 , while the ratio is $>0.5$ for all effluents originating from HTC treatment as shown in Fig. 4 . If the ratio exceeds 0.5 , the waste water is considered to be readily treatable by biological means. Interestingly, the ratio is increased after HTC for effluent from EFB, leaf litter and olive pomace which could possibly be a consequence of the breaking down of larger indigestible organic fragments during HTC to a size that is more easily digested by bacteria.

Anaerobic digestion (AD) could help to access the chemical energy contained in the effluents from washing and HTC.
Fig. $4 \mathrm{BOD}_{5}$ to $\mathrm{COD}$ ratio a and $\mathrm{C}: \mathrm{N}$ ratio $\mathbf{b}$ of effluent from washing and HTC of different biomass feedstock (a)

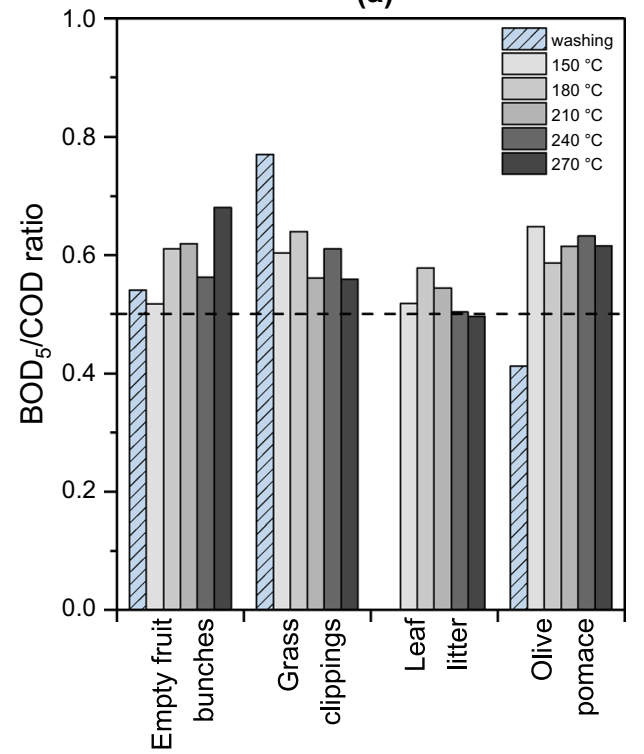

(b)

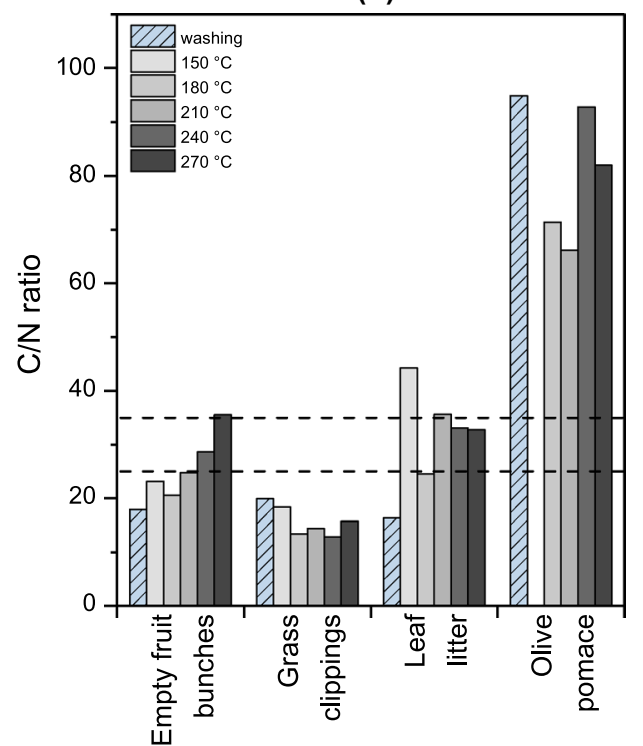


Based on the presented data, a first indication on the potential biogas production from pre-treatment effluents can be made. Biogas production related to COD is about $0.5 \mathrm{lg}^{-1}$ COD removed, corresponding to a methane production of roughly $0.35 \mathrm{~g} \mathrm{~g}^{-1}$ of COD removed [47]. For instance, for a full conversion of $\mathrm{COD}$ to methane, $\mathrm{AD}$ of process water could produce enough methane to cover between $10 \%$ and $20 \%$ of the thermal energy need of the process. This is assuming $2 \mathrm{~m}^{3}$ of effluent, a thermal energy consumption of 1.2 MWh per ton of HTC fuel produced as proposed in literature [21-23]. However a full COD conversion by AD is unlikely. Previous studies have shown that AD is able to eliminate between $50 \%$ and $75 \%$ of COD from HTC effluents $[32,48]$. For other feedstock, the $\mathrm{C} / \mathrm{N}$ ratio can be used as an indicator can be used to evaluate the possible efficiency of an $\mathrm{AD}$ process [49-51]. Fig. $4 \mathrm{~b}$ shows the $\mathrm{C} / \mathrm{N}$ ratio of the obtained effluents from washing and HTC of the different substrates. A value between 25 and 35 is considered optimal. Higher values point to rapid $\mathrm{N}$ depletion, causing lower gas production. A lower value indicates a protein-rich substrate that results in a higher $\mathrm{pH}$ causing methanogenic inhibition. Applying this criteria, an efficient AD conversion is expected for effluent from HTC of EFB and leaf litter. Compared to washing HTC of these feedstock increases $\mathrm{C} / \mathrm{N}$ ratio to the desired range of roughly $25-35$. $\mathrm{C} / \mathrm{N}$ ratio of is below the optimum range for effluent from grass clippings and above the optimum range for effluent from olive pomace. However, $\mathrm{C} / \mathrm{N}$ ratio can only serve as a preliminary assessment, the derived trends need to be verified by further experimental investigations.

\section{Nutrient Contents}

Table 2 shows the concentration of nitrogen nutrients $\left(\mathrm{NO}_{3}-\mathrm{N}, \mathrm{NH}_{4}-\mathrm{N}, \mathrm{NO}_{2}-\mathrm{N}\right)$ and total nitrogen $(\mathrm{TN})$ as well as phosphorous $\left(\mathrm{P}_{\text {tot }}\right)$ determined in effluent samples from washing and HTC of the five investigated feedstock. Compared to the concentrations of organic matter their concentrations are significantly lower.

The most abundant nitrogen nutrient is $\mathrm{NO}_{3}-\mathrm{N}$ with a concentration of $13-117 \mathrm{mg} \mathrm{l}^{-1}$ in effluent from washing and $71-103 \mathrm{mg} \mathrm{l}^{-1}$ in effluent from HTC. When increasing the temperature of leaching from washing at $50{ }^{\circ} \mathrm{C}$ to $150{ }^{\circ} \mathrm{C}$, first an increase of $\mathrm{NO}_{3}-\mathrm{N}$ in the resulting effluent is observed. When further increasing treatment temperature the concentration of $\mathrm{NO}_{3}-\mathrm{N}$ decreases again.

Ammonia- $\mathrm{N}\left(\mathrm{NH}_{4}-\mathrm{N}\right)$ was found in concentrations of 0.5-20.4 $\mathrm{mg} \mathrm{l}^{-1}$ and $0.6-4.8 \mathrm{mg} \mathrm{l}^{-1}$ were in effluent from washing and HTC respectively. For EFB and leaf litter a peak concentration of $34.4 \mathrm{mg}^{-1}$ and $25.6 \mathrm{mg} \mathrm{l}^{-1}$ was measured in effluent from $\mathrm{HTC}$ at $150{ }^{\circ} \mathrm{C}$. In effluent obtained from HTC conducted at $180{ }^{\circ} \mathrm{C}$ and higher the concentration of $\mathrm{NH}_{4}-\mathrm{N}$ rapidly decreases to below $5 \mathrm{mg} \mathrm{l}^{-1}$ for all feedstock. This might indicate the precipitation of ammonia salts under hydrothermal conditions at temperatures above $150{ }^{\circ} \mathrm{C}$, as also suggested by Kruse et al. [52].

Nitrite $\left(\mathrm{NO}_{2}-\mathrm{N}\right)$ was detected in low concentrations for washing $0.36-1.00 \mathrm{mg} \mathrm{l}^{-1}$ and HTC $0.30-1.12 \mathrm{mg} \mathrm{l}^{-1}$. Fluctuations in $\mathrm{NO}_{2}-\mathrm{N}$ concentrations are observed with treatment temperature, but no coherent trend is observed.

Overall, values obtained for $\mathrm{TN}$ in effluent are higher than measured $\mathrm{NO}_{3}-\mathrm{N}, \mathrm{NO}_{2}-\mathrm{N}$ and $\mathrm{NH}_{4}-\mathrm{N}$ concentrations indicating the presence of more organic nitrogen species. After washing TN values are in the range of $25-484 \mathrm{mg} \mathrm{l}^{-1}$, being lower than TN concentrations after HTC. In HTC effluent TN concentrations of $107-1022 \mathrm{mg} \mathrm{l}^{-1}$ were obtained. TN concentration also is feedstock dependent: The highest TN concentrations were measured in effluent from grass clippings, which is also the feedstock that has the highest fuel$\mathrm{N}$ content in the ultimate analysis as presented in Table 1. During washing and HTC nitrogen is released to the process water. The increase in $\mathrm{TN}$ at washing conditions can be explained by the dissolution of water soluble ammonium and nitrite salt and some nitrogen containing compounds to the washing water. At higher temperatures, i.e. at HTC conditions, hydrolysis of nitrogen containing compounds leads to a further increase of TN in the effluent.

Finally, $\mathrm{P}_{\text {tot }}$ values measured seem to be both temperature and feedstock dependent. Highest $P_{\text {tot }}$ values are detected in effluent from grass clippings (up to $238 \mathrm{mg} \mathrm{l}^{-1}$ ), the lowest in effluent from leaf litter (up to $18 \mathrm{mg}^{-1}$ ). For all feedstock a decline in $\mathrm{P}_{\text {tot }}$ in effluent is observed with increasing treatment temperature. For example at washing conditions $238 \mathrm{mg} \mathrm{ml}^{-1}$ of phosphorous is detected in effluent from grass clippings. This value drastically decreases to only $53.4 \mathrm{mg} \mathrm{ml}^{-1}$ at $\mathrm{HTC}$ conditions of $150{ }^{\circ} \mathrm{C}$ and even lower to a value of $4.2 \mathrm{mg} \mathrm{ml}^{-1}$ in effluent originating from HTC of grass clippings at $270{ }^{\circ} \mathrm{C}$. This finding also supports the observations made for phosphorous concentration in the biomass ash which, after an initial decline at washing conditions, increases again for higher treatment temperatures at HTC conditions, as also described by Smith et al. [11]. This suggests that at higher treatment temperature phosphorous is precipitated and reincorporated to the hydrochar.

\section{Conclusion}

The presented study reveals the impact of washing and hydrothermal carbonisation of several feedstock from different biomass types on fuel quality and process water characteristics. Regarding energy density, washing of biomass leads to minor improvements in heating value and elemental composition. In contrast, HTC fundamentally changes the elemental composition of the treated feedstock and increases LHVs drastically. Both washing and HTC alter 
the ash composition of treated feedstock and effectively remove potassium and chlorine, thus reducing the risk of ash-related issues in combustion processes like fouling and corrosion. For the selected feedstock, filtrates from washing and HTC are acidic and the measured electrical conductivity correlates with the amount of electrolytes dissolved in the process water. Both, washing and HTC yield process water that is highly contaminated with organic matter, however $\mathrm{BOD}_{5}$ to COD values indicate good biodegradability of the effluent. AD of the effluents offers $10-20 \%$ potential energy saving from methane production. However, for a reliable assessment of $\mathrm{AD}$ for effluent valorisation further studies, also investigating i.e. the formation of refractory substances are required. Nutrients occur in low concentrations in the effluent from washing and HTC.

Supplementary Information The online version contains supplementary material available at https://doi.org/10.1007/s12649-021-01613-9.

Acknowledgements This project has received funding from the European Union's Horizon 2020 research and innovation programme under Grant Agreement No 727616. Further, I would like to offer my special thanks to Moritz Böhme for his contribution to this work by conducting experiments.

Funding Open Access funding enabled and organized by Projekt DEAL. This project has received funding from the European Union's Horizon 2020 research and innovation programme under Grant Agreement No 727616.

Data Availability Most original data is provided in data tables within the manuscript, the supplementary data includes all other data discussed in this work.

\section{Code Availability Not applicable.}

\section{Declarations}

Conflict of interest Non declared.

Ethical Approval Not applicable.

Consent to Participate Not applicable.

Consent for Publication The authors hereby confirm, that all authors mutually agree for submitting their manuscript and that the manuscript is original work of the authors.

Open Access This article is licensed under a Creative Commons Attribution 4.0 International License, which permits use, sharing, adaptation, distribution and reproduction in any medium or format, as long as you give appropriate credit to the original author(s) and the source, provide a link to the Creative Commons licence, and indicate if changes were made. The images or other third party material in this article are included in the article's Creative Commons licence, unless indicated otherwise in a credit line to the material. If material is not included in the article's Creative Commons licence and your intended use is not permitted by statutory regulation or exceeds the permitted use, you will need to obtain permission directly from the copyright holder. To view a copy of this licence, visit http://creativecommons.org/licenses/by/4.0/.

\section{References}

1. Bryers, R.W.: Fireside slagging, fouling, and high-temperature corrosion of heat-transfer surface due to impurities in steam-raising fuels. Prog. Energy Combust. Sci. 22, 29-120 (1996). https:// doi.org/10.1016/0360-1285(95)00012-7

2. Jenkins, B.M., Baxter, L.L., Miles, T.R.: Combustion properties of biomass. Fuel Process. Technol. 54, 17-46 (1998). https://doi. org/10.1016/S0378-3820(97)00059-3

3. Miles, T.R., Baxter, L.L., Bryers, R.W., et al.: Boiler deposits from firing biomass fuels. Biomass Bioenerg. 10, 125-138 (1996). https://doi.org/10.1016/0961-9534(95)00067-4

4. Zevenhoven-Onderwater M.: Ash-Forming Matter in Biomass Fuels PhD thesis, Department of Chemical Engineering, Åbo Akademi University (2001). ISBN 952-12-0813-9

5. Bahadur, B., Venkat Rajam, M., Sahijram, L., et al.: Plant Biology and Biotechnology. Springer, New Delhi (2015)

6. Engvild, K.C.: Chlorine-containing natural compounds in higher plants. Phytochemistry 25, 781-791 (1986). https://doi.org/10. 1016/0031-9422(86)80002-4

7. Zevenhoven-Onderwater M (2001) Ash-forming matter in biomass fuels. Dissertation. Abo Akademi University, Abo

8. Ekpo, U., Ross, A.B., Camargo-Valero, M.A., et al.: A comparison of product yields and inorganic content in process streams following thermal hydrolysis and hydrothermal processing of microalgae, manure and digestate. Bioresour. Technol. 200, 951-960 (2016). https://doi.org/10.1016/j.biortech.2015.11.018

9. Smith, A.M., Ross, A.B.: The influence of residence time during hydrothermal carbonisation of miscanthus on bio-coal combustion chemistry. Energies 12, 523 (2019). https://doi.org/10.3390/en120 30523

10. Turn, S.Q., Kinoshita, C.M., Ishimura, D.M.: Removal of inorganic constituents of biomass feedstocks by mechanical dewatering and leaching. Biomass Bioenerg. 12, 241-252 (1997). https:// doi.org/10.1016/S0961-9534(97)00005-6

11. Smith, A.M., Singh, S., Ross, A.B.: Fate of inorganic material during hydrothermal carbonisation of biomass: Influence of feedstock on combustion behaviour of hydrochar. Fuel 169, 135-145 (2016). https://doi.org/10.1016/j.fuel.2015.12.006

12. Reza, M.T., Lynam, J.G., Uddin, M.H., et al.: Hydrothermal carbonization: Fate of inorganics. Biomass Bioenerg. 49, 86-94 (2013). https://doi.org/10.1016/j.biombioe.2012.12.004

13. Singhal, A., Konttinen, J., Joronen, T.: Effect of different washing parameters on the fuel properties and elemental composition of wheat straw in water-washing pre-treatment. Part 2: Effect of washing temperature and solid-to-liquid ratio. Fuel 94, 120209 (2021). https://doi.org/10.1016/j.fuel.2021.120209

14. Ma, Q., Han, L., Huang, G.: Evaluation of different water-washing treatments effects on wheat straw combustion properties. Bioresour. Technol. 245, 1075-1083 (2017). https://doi.org/10.1016/j. biortech.2017.09.052

15. Deng, L., Zhang, T., Che, D.: Effect of water washing on fuel properties, pyrolysis and combustion characteristics, and ash fusibility of biomass. Fuel Process. Technol. 106, 712-720 (2013). https://doi.org/10.1016/j.fuproc.2012.10.006

16. Wu, S., Chen, J., Peng, D., et al.: Effects of water leaching on the ash sintering problems of wheat straw. Energies 12, 387 (2019). https://doi.org/10.3390/en12030387 
17. Singhal, A., Konttinen, J., Joronen, T.: Effect of different washing parameters on the fuel properties and elemental composition of wheat straw in water-washing pre-treatment. Part 1: Effect of washing duration and biomass size. Fuel 16, 120206 (2021). https://doi.org/10.1016/j.fuel.2021.120206

18. Miles TR, Miles TR, JR., Baxter LL et al. (1995) Alkali deposits found in biomass power plants: A preliminary investigation of their extent and nature. Volume 1

19. Bandura, A.V., Lvov, S.N.: The ionization constant of water over wide ranges of temperature and density. J. Phys. Chem. Ref. Data 35, 15-30 (2006). https://doi.org/10.1063/1.1928231

20. Smith, A.M., Ekpo, U., Ross, A.B.: The influence of $\mathrm{pH}$ on the combustion properties of bio-coal following hydrothermal treatment of swine manure. Energies 13, 331 (2020). https://doi.org/ 10.3390/en 13020331

21. Stemann, J., Erlach, B., Ziegler, F.: Hydrothermal carbonisation of empty palm oil fruit bunches: laboratory trials, plant simulation, carbon avoidance, and economic feasibility. Waste Biomass Valor. 4, 441-454 (2013). https://doi.org/10.1007/s12649-012-9190-y

22. Saba, A., McGaughy, K., Reza, M.: Techno-economic assessment of Co-hydrothermal carbonization of a coal-miscanthus blend. Energies 12, 630 (2019). https://doi.org/10.3390/en12040630

23. Lucian, M., Fiori, L.: Hydrothermal carbonization of waste biomass: Process design, modeling, energy efficiency and cost analysis. Energies 10, 211 (2017). https://doi.org/10.3390/en10020211

24. Stemann, J., Putschew, A., Ziegler, F.: Hydrothermal carbonization: process water characterization and effects of water recirculation. Bioresour. Technol. 143, 139-146 (2013). https://doi.org/10. 1016/j.biortech.2013.05.098

25. Wang, F., Wang, J., Gu, C., et al.: Effects of process water recirculation on solid and liquid products from hydrothermal carbonization of Laminaria. Bioresour. Technol. 292, 121996 (2019). https://doi.org/10.1016/j.biortech.2019.121996

26. Broch, A., Jena, U., Hoekman, S., et al.: Analysis of solid and aqueous phase products from hydrothermal carbonization of whole and lipid-extracted algae. Energies 7, 62-79 (2014). https:// doi.org/10.3390/en7010062

27. Reza, M.T., Wirth, B., Lüder, U., et al.: Behavior of selected hydrolyzed and dehydrated products during hydrothermal carbonization of biomass. Bioresour. Technol. 169, 352-361 (2014). https://doi.org/10.1016/j.biortech.2014.07.010

28. Köchermann, J., Görsch, K., Wirth, B., et al.: Hydrothermal carbonization: Temperature influence on hydrochar and aqueous phase composition during process water recirculation. J. Environ. Chem. Eng. 6, 5481-5487 (2018). https://doi.org/10.1016/j.jece. 2018.07.053

29. Becker, R., Dorgerloh, U., Paulke, E., et al.: Hydrothermal carbonization of biomass: Major organic components of the aqueous phase. Chem. Eng. Technol. 37, 511-518 (2014). https://doi.org/ 10.1002/ceat.201300401

30. Yue, F., Pedersen, C.M., Yan, X., et al.: NMR studies of stock process water and reaction pathways in hydrothermal carbonization of furfural residue. Green Energy Environ. 3, 163-171 (2018). https://doi.org/10.1016/j.gee.2017.08.006

31. Weiner, B., Wedwitschka, H., Poerschmann, J., et al.: Utilization of Organosolv waste waters as liquid phase for hydrothermal carbonization of chaff. ACS Sustain. Chem. Eng. 4, 5737-5742 (2016). https://doi.org/10.1021/acssuschemeng.6b01665

32. Wirth, B., Reza, T., Mumme, J.: Influence of digestion temperature and organic loading rate on the continuous anaerobic treatment of process liquor from hydrothermal carbonization of sewage sludge. Bioresour. Technol. 198, 215-222 (2015). https://doi.org/ 10.1016/j.biortech.2015.09.022

33. Wirth, B., Mumme, J.: Anaerobic digestion of waste water from hydrothermal carbonization of corn silage. Appl. Bioenergy (2014). https://doi.org/10.2478/apbi-2013-0001
34. Marin-Batista, J.D., Villamil, J.A., Qaramaleki, S.V., et al.: Energy valorization of cow manure by hydrothermal carbonization and anaerobic digestion. Renew. Energy 160, 623-632 (2020). https:// doi.org/10.1016/j.renene.2020.07.003

35. Erdogan, E., Atila, B., Mumme, J., et al.: Characterization of products from hydrothermal carbonization of orange pomace including anaerobic digestibility of process liquor. Bioresour. Technol. 196, 35-42 (2015). https://doi.org/10.1016/j.biortech.2015.06.115

36. Villamil, J.A., Mohedano, A.F., Rodriguez, J.J., et al.: Valorisation of the liquid fraction from hydrothermal carbonisation of sewage sludge by anaerobic digestion. J. Chem. Technol. Biotechnol. 93, 450-456 (2018). https://doi.org/10.1002/jctb.5375

37. Abelha, P., Kiel, J.: Techno-economic assessment of biomass upgrading by washing and torrefaction. Biomass Bioenerg. 142, 105751 (2020). https://doi.org/10.1016/j.biombioe.2020.105751

38. Kruse, A., Funke, A., Titirici, M.-M.: Hydrothermal conversion of biomass to fuels and energetic materials. Curr. Opin. Chem. Biol. 17, 515-521 (2013). https://doi.org/10.1016/j.cbpa.2013.05.004

39. Libra, J.A., Ro, K.S., Kammann, C., et al.: Hydrothermal carbonization of biomass residuals: a comparative review of the chemistry, processes and applications of wet and dry pyrolysis. Biofuels 2, 71-106 (2011). https://doi.org/10.4155/bfs.10.81

40. Lynam, J.G., Reza, M.T., Yan, W., et al.: Hydrothermal carbonization of various lignocellulosic biomass. Biomass Conv. Bioref. 5, 173-181 (2015). https://doi.org/10.1007/s13399-014-0137-3

41. Hoekman, S.K., Broch, A., Robbins, C.: Hydrothermal carbonization (HTC) of lignocellulosic biomass. Energy Fuels 25, 18021810 (2011). https://doi.org/10.1021/ef101745n

42. Reza, M.T., Lynam, J.G., Vasquez, V.R., et al.: Pelletization of biochar from hydrothermally carbonized wood. Environ. Prog. Sustain. Energy 31, 225-234 (2012). https://doi.org/10.1002/ep. 11615

43. Kambo, H.S., Dutta, A.: Strength, storage, and combustion characteristics of densified lignocellulosic biomass produced via torrefaction and hydrothermal carbonization. Appl. Energy 135, 182-191 (2014). https://doi.org/10.1016/j.apenergy.2014.08.094

44. Acharjee, T.C., Coronella, C.J., Vasquez, V.R.: Effect of thermal pretreatment on equilibrium moisture content of lignocellulosic biomass. Bioresour. Technol. 102, 4849-4854 (2011). https://doi. org/10.1016/j.biortech.2011.01.018

45. Kambo, H.S., Minaret, J., Dutta, A.: Process water from the hydrothermal carbonization of biomass: A waste or a valuable product? Waste Biomass. Valor. 9, 1181-1189 (2018). https://doi.org/10. 1007/s12649-017-9914-0

46. Berge, N.D., Ro, K.S., Mao, J., et al.: Hydrothermal carbonization of municipal waste streams. Environ. Sci. Technol. 45, 5696-5703 (2011). https://doi.org/10.1021/es2004528

47. Angelidaki, I., Alves, M., Bolzonella, D., et al.: Defining the biomethane potential (BMP) of solid organic wastes and energy crops: a proposed protocol for batch assays. Water Sci. Technol. 59, 927-934 (2009). https://doi.org/10.2166/wst.2009.040

48. Blöhse, D.: Hydrothermale Karbonisierung - Nutzen dieser Konversionstechnik für die optimierte Entsorgung feuchter Massenreststoffe. Universitätsbibliothek Duisburg-Essen, Duisburg, Essen (2017)

49. Gerardi, M.H.: The microbiology of anaerobic digesters. Wastewater microbiology series. Wiley, Hoboken, New Jersey (2003)

50. Kwietniewska, E., Tys, J.: Process characteristics, inhibition factors and methane yields of anaerobic digestion process, with particular focus on microalgal biomass fermentation. Renew. Sustain. Energy Rev. 34, 491-500 (2014). https://doi.org/10.1016/j.rser. 2014.03.041

51. Khalid, A., Arshad, M., Anjum, M., et al.: The anaerobic digestion of solid organic waste. Waste Manag 31, 1737-1744 (2011). https://doi.org/10.1016/j.wasman.2011.03.021 
52. Kruse, A., Koch, F., Stelzl, K., et al.: Fate of nitrogen during hydrothermal carbonization. Energy Fuels 30, 8037-8042 (2016). https://doi.org/10.1021/acs.energyfuels.6b01312
Publisher's Note Springer Nature remains neutral with regard to jurisdictional claims in published maps and institutional affiliations. 